Boston University School of Law

Scholarly Commons at Boston University School of Law

Faculty Scholarship

$4-2015$

\title{
Gaps and Changed Circumstances in Energy Contracts: The Devil in the Detail
}

William W. Park

Boston University School of Law

Follow this and additional works at: https://scholarship.law.bu.edu/faculty_scholarship

Part of the Energy and Utilities Law Commons

\section{Recommended Citation}

William W. Park, Gaps and Changed Circumstances in Energy Contracts: The Devil in the Detail , in 8 Journal of World Energy Law \& Business 89 (2015).

Available at: https://scholarship.law.bu.edu/faculty_scholarship/12

This Article is brought to you for free and open access by Scholarly Commons at Boston University School of Law. It has been accepted for inclusion in Faculty Scholarship by an authorized administrator of Scholarly Commons at Boston University School of Law. For more information, please contact lawlessa@bu.edu. 


\title{
BU School of Law
}

\section{GAPS AND CHANGED CIRCUMSTANCES IN ENERGY CONTRACTS: THE DEVIL IN THE DETAIL}

8 J. World Energy Law \& Business 89 (2015)

Boston University School of Law Public Law \& Legal Theory Paper No. 15-17

(April 14, 2015)

\author{
William W. Park \\ Boston University School of Law
}

This paper can be downloaded without charge at:

http://www.bu.edu/law/faculty/scholarship/workingpapers/2015.html 


\title{
Gaps and changed circumstances in energy contracts: the devil in the detail
}

\author{
William W. Park*
}

Energy contracts have long been vexed by questions about the role of gap filling by arbitrators and judges, along with the effect of changed circumstance on the parties' obligations. Each challenge continues to resist facile analysis as differing legal standards interact with subtleties of contract language and factual matrixes. In the face of these challenges, arbitrators must seek a delicate equilibrium between legitimate respect for bargains and an equally legitimate recognition of expectations that genuine gaps be filled and dramatically changed circumstances receive appropriate consideration. In aiming for counterpoise, common sense normally pays greater dividends than ideology or dogmatism.

'General propositions do not decide concrete cases'

Justice Oliver Wendell Holmes ${ }^{1}$

\section{Premises and facts}

\section{A cautionary note}

Like the adage from Justice Holmes about general propositions not deciding concrete cases, ${ }^{2}$ the catchphrase 'devil in the detail' often serves to emphasize how implementation of a general principle depends on the matrix of its application. ${ }^{3}$ Not many of us oppose justice and fair dealing. However, we often disagree on what constitutes injustice and bad faith in the particularity of given circumstances.

* William W Park, Professor of Law, Boston University; President, London Court of International Arbitration; General Editor, Arbitration International. (C) The Author 2015. Published by Oxford University Press on behalf of the AIPN. All rights reserved.

$1 \quad$ Dissent in Lochner $v$ New York (1905) 198 US 45, 76.

2 Itself a broad generality, Holmes' adage took aim at economic theories of Herbert Spencer, a British polymath whose 'survival of the fittest' formulation of Social Darwinism purportedly influenced a majority on the US Supreme Court to find that freedom of contract precluded New York from limiting work hours to protect the health of bakers. Such employment regulations were deemed to run afoul of the Constitution's 14th Amendment, which prohibits taking property without due process of law.

3 The phrase seems to derive from an earlier expression that 'God is in the detail' attributed first to the French writer Gustave Flaubert ('Le bon Dieu est dans le detail') and subsequently to the German-American architect Ludwig Mies van der Rohe. 
This cautionary note applies with special force in assessing the way contract gaps and changed economic realities affect long-term energy agreements. Differences large and small separate the national legal systems that govern such arrangements, as well as the nature of gaps and altered conditions. It would take a very brave scholar indeed to propose too many overarching normative premises.

The applicable law can provide guidance on how (if at all) a contract should reflect new events. Some legal systems seem to take a relatively strict 'deal is a deal' approach, ${ }^{4}$ while others allow more liberal adjustment of terms under theories like 'abuse of right' or good faith. ${ }^{5}$ The text of an agreement also may say things about how changed circumstances affect contract relationships. Some agreements include explicit instructions for modifying contract terms in the face of a substantial change in the economic environment. ${ }^{6}$

The various tools of contract construction separate themselves from each other by rather porous membranes. One case or commentator might speak of 'hardship' affecting contract performance. ${ }^{7}$ Another might refer to the effect of unforeseen events. Yet, a third observer invokes 'bouleversement' (economic upheaval) as a source for adjustment of contract terms. All approaches relate to adjustment of an agreement to reflect events which, for one side or the other, represent dramatically altered commercial circumstances.

Notions of foreseeability play a vital role in commercial risk allocation, somewhat analogous to the way fortuity operates in insurance. ${ }^{8}$ Bargains should not be shirked through invocation of predicable events. In excluding the impact of circumstances that are foreseeable, contracts require analysis of randomness, which might be termed aléatoire or Zufallsbedingt in certain Continental legal systems.

When risk allocation occurs through explicit contract language, seemingly subtle word choices may be determinative. Concepts of "foreseeable" and "not unforeseeable" can work themselves out quite differently in practice. Imagine that a buyer agrees to bear any "foreseeable" taxes on a particular transaction. Now consider a slight adjustment, with the buyer agreeing to bear taxes that are "not unforeseeable." The latter formulation ("not unforeseeable") might include a larger universe than the former ("foreseeable") if relevant fiscal legislation was debated at the time of contract negotiation but not enacted until later. ${ }^{9}$ Although the opposite of foreseeable is unforeseeable, we do not necessarily return to the starting point (foreseeable) just by adding another negative.

4 See eg tests for frustration in English law as set forth in Chitty on Contract (31st edn, 2013), s 23-005 describing the standard as to be kept within 'very narrow limits [and] not to be extended'. Citing Bank Line Ltd v Arthur Capel \& Col [1919] AC 435, 459. But see emerging notions of 'good faith' in England discussed below.

See eg discussion of art 2 of the Swiss Code des Obligations, below.

See discussion of the Atlantic LNG case (n 12).

See eg Frederick R Fucci, 'Hardship and Changed Circumstances as Grounds for Adjustment or Non-Performance of Contracts' (2007) 5 OGEL adapted from ABA Section of International Law, New York, April 2006.

8 An uncertainty might exist about when something will occur (death covered by life insurance) or whether an event will happen at all (flood or fire under a homeowners' policy, or third-party harm covered by liability insurance).

9 To illustrate from meteorology, New England weather patterns make it "not unforeseeable" to have snow in Boston at Christmastime. Yet only in some years would snow at Christmas be foreseeable, depending on how far in advance one forecasts. Further north the odds make snow both foreseeable and "not unforeseeable" while in Miami the prospect of snow on Christmas would be neither. 


\section{Two illustrative cases}

Two cases illustrate the complexities that can arise when arbitrators address claims based on alleged changes in circumstances. In one, Swiss courts filled lacunae in an agreement to supply hydro-power, allowing the sale of excess energy in a fashion not foreseen in the original contract. The second matter implicated arbitrators sitting in New York who fixed a new price formula for a long-term gas supply agreement.

Although gap filling remains distinct from price adjustment, each exercise implicates the addition of some element beyond the mix of rights and duties explicit in the signed document. With respect to both the Swiss hydro-power case and the gas price arbitration, the passage of time brought changes in economic conditions which affected the use and value of the purchased commodity. Unlike the Swiss case, however, the gas arbitration implicated a power to adjust the price, expressly conferred by contract, rather than gap filling under applicable law.

\section{The Gornergrat railway}

The story opens in 1895, with a 99-year hydro-concession by an Alpine community nestled in the shadow of the fabled Matterhorn, which has attracted climbers for a good part of two centuries. ${ }^{10}$ The grant covered water power from the Findelenbach River but not for just any purpose. The energy was to be harnessed to operate the first electric rack railway in Switzerland, running from the centre of Zermatt village to the summit of a nearby mountain.

Decades later, the railway wished to sell surplus power, a matter not addressed when the contract was concluded. The village granting the concession asserted a right to preapprove, with conditions, sale of any excess energy not needed for the railway. In the early days of the contract, the question had never arisen.

In the face of immoderate positions on both sides, the cantonal court allowed the sale of excess energy by the railway, but only in a way that did not hurt the legitimate interests of the municipality. However, the somewhat indeterminate way the matter was addressed led the Swiss Federal Supreme Court (Bundesgricht/Tribunal fédéral) to engage in further analysis.

Although the two parties denied the existence of lacunae in their agreement, the court described its role as gap filling ('die Lückenausfüllung') in a way that applied notions of good faith common to both public and private law. ${ }^{11}$ Finding it unreasonable to prevent all usage of excess power, the court took pains not to give the railway a completely free hand either. Notably, the railway was not permitted to compete with the municipality in selling electricity to residents, but could market the power to outsiders, in particular, to another railway line that ran down the valley to the town of Visp. The court stressed the

10 Gornergratbahn-Gesellschaft gegen Munizipal- und Burgergemeinde Zermatt, Decision of 21 March 1935 in ATF 61 I 65-79. Review by the Tribunal feédeéral (Bundesgericht) of a decision by the cantonal court in Valais/Wallis. The grant implicated two collectivities: the municipality in the modern sense, and a group of families (Bürgergemeinde) which since medieval times held local rights as free citizen townsmen, or 'bourgeois' in the original sense of the term. For ease of reference these groups are treated together in their opposition to the railway.

11 ibid 75-75. The Bundesgericht spoke of 'eine mittlere Lösung' in taking a middle position that neither side had requested. 
need for specificity in gap filling, insisting on a price per kilowatt hours along the lines of a draft settlement that had been contemplated several years earlier. ${ }^{12}$

\section{The Atlantic LNG price adjustment}

Three quarters of a century after the Gornergrat railway case, the sale of liquefied natural gas led to one of the few gas price adjustment arbitrations to reach the public eye. A Trinidadian supplier (Atlantic LNG) had concluded a 20-year contract with a Spanish buyer (Gas Natural). ${ }^{13}$ Although Spain was the primary market for the gas, the contract specified that the buyer could transport gas to facilities in either Spain or New England.

An initial formula specified a base price indexed to certain European petroleum products. Either side could request revision of that formula on establishing that certain preconditions had been met. In pertinent part, Section 8.5 of the agreement provided as follows:

If at any time either Party considers that economic circumstances in Spain beyond the control of the Parties, while exercising due diligence, have substantially changed as compared to what it reasonably expected when entering into this Contract ... and the Contract Price resulting from application of the [original price formula] does not reflect the value of Natural Gas in the Buyer's end user market, then such Party may... request that the Parties should forthwith enter into negotiations to determine whether or not such changed circumstances exist and justify a revision of the Contract Price provisions and, if so, to seek agreement on a fair and equitable revision of [the contract price].

Failing agreement on a new formula within six months, either party could submit the matter to arbitration for decision in accordance with the criteria set out in the 'price reopener' provision.

When Spain's natural gas prices decreased, the buyer began reselling in the more attractive New England market. The seller then sought an upward revision of the price formula to obtain a share of the greater value being obtained by the buyer on resale. On the parties' failure to agree, the matter was referred to arbitration.

Having determined that the buyer's end-user market was either Spain or New England, depending on destination of the gas, the tribunal instituted a two-part pricing scheme. The Spanish formula was retained with a reduced base component. However, a New England price was added for periods when the buyer decided to re-sell a defined percentage for delivery to New England receiving facilities. The operation of this new scheme resulted in the Trinidadian seller owing the Spanish buyer a retroactive rebate of

12 Over the years, Swiss case law has further refined the contours of the gap filling, addressing matters such as whether the omitted term was essential or not, and whether a meeting of the minds had been reached.

13 Gas Natural Aprovisionamientos v Atlantic LNG Co. of Trinidad Tobago (2008) WL 4344525 (SDNY 2008). 
approximately $\$ 70$ million for prior deliveries, as well as possibly yielding substantial prospective changes depending on how markets evolved.

In American federal court, the buyer moved to confirm the award, while the Trinidadian seller applied for vacatur and opposed recognition. The seller contended inter alia that the arbitrators exceeded their authority by creating a two-part pricing scheme that effectively rewrote the agreement.

According to the seller, the dual structure distorted the parties' original bargain. By shifting deliveries, the buyer could determine which of two prices would apply to all shipments, whether to the higher or the lower market. For example the buyer might take 100 units and resell 51\% to Spanish users, with the rest going to New England. Assuming a 51\% threshold for determining which price applied, and assuming further a Spanish market below that of New England, the buyer would pay the lesser price (fixed by reference to Spain) on all gas bought from seller, even those quantities for delivery to New England where resale resulted in higher returns.

The court rejected the seller's contention that grounds existed for vacatur or nonrecognition of the award under the Federal Arbitration Act. In this connection, the decision noted broad contract language providing for a 'fair and equitable revision' and the parties' failure to set limits on, or to prohibit, a dual-pricing structure.

\section{Frameworks for decision making}

\section{Fidelity to the parties' expectations}

When circumstances change, some right or duty might be asserted beyond what appeared on the face of the agreement as initially drafted. The boundaries between contract interpretation and gap filling can seem thin when the applicable law permits insertion of an omitted term ${ }^{14}$ or supplies a general rule of decision which directs how silence will be construed. ${ }^{15}$ Often the parties could easily have addressed the controverted matter explicitly, but did not. ${ }^{16}$

Each exercise implicates fidelity to the parties' shared pre-dispute expectations as best they can be ascertained. For conscientious arbitrators and judges, neither gap filling nor

14 See eg Restatement, Second, Contracts s $204 \mathrm{cmt}$ a ('the supplying of an omitted term is not technically interpretation, but the two are closely related'). See also Randy E Barnett, 'The Sound of Silence: Default Rules and Contractual Consent' (1992) 78 V LR 821. See generally E Allan Farnsworth, Contracts (2nd edn, 1990), ss 7.15-7.17, 540-59, illustrating with a case involving a publicity plane carrying a streamer urging British crowds to 'Eat Batchelor's Peas' just as they were observing two minutes of silence to honour the dead fallen in the First World War. The ill-timed publicity led a number of potential customers to declare that the advertised goods would never enter their households. In holding the advertising agency liable for damages, the court struggled with the absence of any term excluding flying on Armistice Day. Aerial Advertising Co. v Batchelor's Peas [1938] 2 All ER 788.

15 For example, insurance for third-party liability might provide that insurers cannot refuse unreasonably to approve a reasonable settlement. Or the policy might be silent on the point, but yield a similar result through an applicable law imposing an analogous restriction on the insurer's freedom to deny coverage, through an implied duty of good faith. See Luria Bros. \& Co. v Alliance Assurance Co. Ltd, 780 F 2d 1082 (2d Cir 1986). Of course, the insurer might insist on an unequivocal policy provision to the effect that 'no settlements will be authorized' coupled with designation of an applicable law containing no duty of good faith. Whether many of such policies would be sold would be another question.

16 Alan Scott Rau, Gap Filling by Arbitrators (International Council for Commercial Arbitration, Miami, April 2014) <http://ssrn. com/abstract=2435232> (forthcoming, ICCA Congress Series, 2015). Professor Rau suggests that the very concept a 'gap' remains fleeting, meaning everything and nothing. Some might argue that by definition a contract will be complete, while for others contracts contain 'nothing but gaps unless the parties have taken the pains to construct an infinite agreement mapping onto every conceivable state of the world, likely or unlikely, known or unknown'. 
construing silence warrants rewriting an agreement. Likewise, any legitimate adjustment of terms will respect the contours and pre-requisites of the relevant law or contract framework.

In some instances, an arbitrator might be asked to provide an essential term such as the sale price. Many legal systems foresee potential judicial intervention to fix such omitted terms if the parties intended to be bound. In the USA, the Uniform Commercial Code allows a 'reasonable' price to be fixed in terms of an agreed market or other standard established by a third person. ${ }^{17}$ Intent to be bound might be determined from a course of dealing.

On other occasions, an arbitrator might find an implied term which, although not essential, will affect significantly the way the dispute is decided. ${ }^{18}$ In this connection, American courts have recently addressed requests for collective arbitration brought by multiple claimants pursuant to a large number of contracts, as contrasted with bilateral proceedings between two sides arising from the same agreement. ${ }^{19}$

When an agreement fails to contain explicit provisions on collective action (such as "class arbitration allowed" or "class arbitration forbidden") an arbitrator or a court must construe the seeming silence in light of context or other contract provisions. ${ }^{20}$ In one instance, a unanimous US Supreme Court confirmed an arbitrator's decision interpreting silence as permission for class arbitration. ${ }^{21}$ Yet the same Court, faced with different facts, vacated for excess of authority another award interpreting silence to permit class arbitration. $^{22}$

17 See UCC s 2-305 (Open Price Term) providing that if the parties so intend they can conclude a sale contract even though the price is not settled, in which case the price will be one 'reasonable at the time for delivery' if (i) nothing is said as to price; or (ii) the price is left to be agreed by the parties and they fail to agree; or (iii) the price is to be fixed in terms of some agreed market or other standard as set or recorded by a third person or agency and it is not so set or recorded. The UCC continues that there is no contract when the parties intend not to be bound unless the price is fixed, and in fact it is not agreed. See also UCC $s$ 2-204(3), to the effect that 'a contract for sale does not fail for indefiniteness if the parties have intended to make a contract and there is a reasonably certain basis for giving an appropriate remedy'.

18 Common non-controversial examples include an arbitrator's right to direct standards for document production, to bifurcate proceedings or to fix briefing schedules, all matters that might be addressed explicitly in the arbitration clause, but would fall within the purview of arbitral authority when omitted from the contract.

19 Likewise, institutional arbitration rules might provide guidance for handling requests to join new parties or consolidate arbitrations for multiple contracts. See eg, arts 7-10 of the 2012 ICC Arbitration Rules, discussed in William W Park, The Role of Law in Arbitration (OUP forthcoming 2016).

20 One recalls the old joke comparing different legal systems: the French allow all which is not forbidden, while the Germans prohibit all which is not allowed. And in North Korea, anything not forbidden is compulsory.

21 Oxford Health Plans LLC v Sutter, 133 S Ct 2064 (2013). The opinion by Justice Kagan notes that the parties agreed that 'an arbitrator should determine what their contract meant, including whether its terms approved class arbitration. The arbitrator did what the parties requested: He provided an interpretation of the contract resolving that disputed issue.... Under [Federal Arbitration Act] $\S 10(\mathrm{a})(4)$, the question for a judge is not whether the arbitrator construed the parties' contract correctly, but whether he construed it at all'. The concurrence by Justices Alito and Thomas notes that in this instance the claimant health plans conceded that the arbitrator should determine what the contract meant, including whether its terms approved class arbitration.

22 Stolt-Nielsen S.A. $v$ AnimalFeeds Int'l Corp. (2010) 559 US 662. The Court rightly noted the parties' litigation stipulation to the effect that 'no agreement' was reached on class arbitration, which went beyond saying the contract was silent. The stipulation seemed to preclude finding an implied term, given that the parties expressly said they did not agree even by implication. The Court may have answered the wrong question, addressing whether the parties agreed to class arbitration, rather than focusing on the relevant inquiry under the Federal Arbitration Act: 'What did the parties agree to arbitrate?' By adopting the AAA Supplementary Rules for Class Arbitrations, the parties provided for arbitrators to decide whether the contract allowed class arbitration. See William W. Park, Arbitration of International Business Disputes (2nd edn, 2012), 97 ff. 


\section{Amiable composition}

Litigants sometimes empower an arbitrator to depart from the contract or applicable law, deciding in a way that the arbitrators deem fair and equitable. Drawn from French law, the notion of amiable composition describes a process whereby arbitrators temper legal rules, whose strict application violates what seems commercially reasonable in the circumstances. ${ }^{23}$ Common examples include payments related to substantial completion of a project, or adjustment of terms to reflect unexpected currency fluctuations.

In stipulating to amiable composition, parties tell arbitrators to reach towards general notions of 'right' with overtones that operate in tension with court decisions, statutes or strict contract terms. ${ }^{24}$ These notions bear some similarity to what, in insurance arbitration, has been known as the 'honorable engagement' clause. Some reinsurance agreements include clauses that might provide as follows:

The arbitrators and Umpire [ie third member of the tribunal, not designated by either side] shall interpret this Agreement as an honorable engagement, and shall not be obligated to follow the strict rules of law or evidence. In making their award, they shall apply the custom and practice of the insurance and reinsurance industry, with a view to effecting the general purpose of the Agreement. ${ }^{25}$

Along similar lines, the first President of the United States provided in his will that disputes among heirs were to be arbitrated by 'three impartial and intelligent men' who would declare the testator's intention 'unfettered by law or legal constructions' ${ }^{26}$

A long-standing debate surrounds whether amiable composition amounts to the same thing as decision making ex aequo et bono, according to the 'right and good'. ${ }^{27}$ While the two notions are often used interchangeably, they may not be coextensive in all minds. Arbitrators who decide ex aequo et bono might begin and end with a private sense of justice, going directly to a personal view of the right result. By contrast, with amiable

23 See French Code of Civil Procedure art 1478 applicable in purely domestic arbitrations ('Le tribunal arbitral tranche le litige conformément aux règles de droit, à moins que les parties lui aient confié la mission de statuer en amiable composition.') and its analogue for international cases in art 1512 (Le tribunal arbitral statue en amiable composition si les parties lui ont confié cette mission). See Eric Loquin, L'amiable composition en droit comparé et international: Contribution à l'étude du non-droit dans l'arbitrage commercial (1980), juxtaposing 'non-droit' (non law) and 'droit comparé' (comparative law). See also, W Laurence Craig, William W Park and Jan Paulsson, ICC Arbitration (3rd edn, 2000), s 3.05, 110-14. It may well be that references to amiable composition assume a less precise contour in international arbitration than under French law, much as notions of 'due process' used in international arbitration can depart from the narrower meaning in American law.

24 See Mathieu de Boisséson, Le droit français de l'arbitrage (1990), s 371, 315, suggesting that equité remains the goal (le but) not the means (le moyen) of amiable composition.

25 ARIAS US, Practical Guide to Reinsurance Arbitration Procedure, Illustration 1.1 (US Insurance \& Reinsurance Arbitration Society).

26 See WW Abbot (ed), Papers of George Washington, Retirement Series, vol 4 (University Press of Virginia 1999) 477-92. The will was dated at Mount Vernon on 9 July 1979, five months before Washington died of a throat infection, having enjoyed less than three years of his well-earned retirement. An interesting question remains about the extent to which such a provision can bind heirs who did not agree to the arbitration.

27 Art 21(3) of the ICC Arbitration Rules permits amiable composition only if agreed by the parties. The French and English texts alike mention both the power of amiable compositeur and decision ex aequo et bono, joining the concepts with the disjunctive 'or' ('ou' in the French text) thus leaving open a possibility that the phrases might designate distinct notions, as in 'law or equity'. Of course, joining words with 'or' sometimes suggests simply different ways to express similar concepts, as when each citizen worships according his faith or conviction. 
composition, arbitrators start at rules of law, departing only if needed to achieve a just result. $^{28}$ The difference is significant, given that there is nothing inherently unjust about most norms of commercial law.

With respect to the substance of economic transactions, such as a seller's right to be paid or the buyer's right to receive the promised commodity, most business managers understandably distrust notions such as ad hoc justice, whose slim objective content may not supply the information needed to evaluate risks and make choices. Nor will concepts of fairness divorced from law satisfy the public interest in a stable economic environment that promotes economic cooperation enhanced by reliable vindication of ex ante expectations, with similar cases decided pursuant to similar norms. ${ }^{29}$

Consequently, only an explicit mandate normally justifies an arbitrator's shift from a search for the law to the pursuit of subjective fairness. Among the objectives of the arbitral process, one goal is to get it right. This does not mean, of course, an endless search for absolute truth such as might exist in the mind of God, but rather reaching a reasonable view of what happened, what the contract says, and what the applicable law provides. $^{30}$

\section{National law}

\section{Good faith, Abus de droit, Treu und Glauben}

Among the provisions of national law that permit adjustment of contract terms, ${ }^{31}$ the most notable rely on theories of 'good faith' and 'abuse of rights' (as in Switzerland) ${ }^{32}$ or notions such as Treu und Glauben (in Germany). ${ }^{33}$ Although the notion of 'good faith' has not always found favour in English law, recent cases may

28 See Philippe Fouchard, Emmanuel Gaillard and Berthold Goldman, Traité de l'arbitrage commercial international (1996), s $1502,836-37$. The authors seem to admit the option either to proceed directly to justice or first to consider the applicable law. Nevertheless, they suggest that such a nuance lacks significance ('une telle distinction ... parait artificielle') because the arbitrators can always do what they think justice requires.

29 Imagine an arbitrator hearing claims against an employer who wrongfully refused to pay a worker's full salary. 'Last month we agreed to $\$ 1,500$ ', says the worker. 'Ah, yes', replies the employer. 'However, such dreary historical facts must yield to concerns for balance and charity. So we have rounded your pay down to $\$ 1000$ and transferred the balance to the Red Cross.'

30 On occasion, eloquent defences of infidelity to shared expectations advance themselves with phrases such as 'light from yesterday's lamp' in reference to existing legal standards. However sincere the speakers, such phrases risk ending as pretexts for ad hoc decision making not worthy of commercial arbitration pursuant to clauses drafted by sophisticated business managers.

31 For a comprehensive tour d'horizon of contract adjustment, see Joachim G. Frick, Arbitration and Complex International Contracts (Zürich 2001), Pt III, 145-226, addressing in particular the matter of 'gap filling' in complex agreements, adaptation clauses, the duty to re-negotiate, an arbitrator's power to adjust contract terms, notions of 'changed circumstances', and lex mercatoria derived from arbitral awards. See also Nagla Nassan, Sanctity of Contract Revisited: A Study in the Theory and Practice of Long Term International Commercial Transactions (1995).

32 Art 2 of Swiss Code civil. Compare to art 1134(3) of French Code civil, which speaks of abuse of contracts (conventions) rather than rights (droits), derived from the notion that contracts must be executed in good faith.

33 German Civil Code (ZPO) in s 162(2) provides inter alia, 'If the satisfaction of a condition is brought about in bad faith by the party to whose advantage it would be, the condition is deemed not to have been satisfied.' ('Wird der Eintritt der Bedingung von der Partei, zu deren Vorteil er gereicht, wider Treu und Glauben herbeigeführt, so gilt der Eintritt als nicht erfolgt.') See also art 242, concerning the obligator's duty to perform obligations according to the requirements of good faith, taking into account custom and practice. 
suggest duties beyond the contours of the strict contract terms. ${ }^{34}$ Courts in the United States have tended to resist excusing performance because of frustration, impossibility or impracticality, ${ }^{35}$ and have been skeptical of arguments that dramatically changed circumstances require 'good faith' re-negotiation of freely accepted contract terms. ${ }^{36}$ Market increases would not normally fall within the range of unforeseeable events. ${ }^{37}$ Other national legal systems take different views on related notions such as force majeure and imprévision (France), ${ }^{38}$ excessiva onerositá (Italy), ${ }^{39}$ or unmöglichkeit (Germany). ${ }^{40}$

Sometimes, a duty to re-negotiate might arguably exist under principles of international trade law, occasionally called lex mercatoria, for better or for worse. Such a duty may arise in the case of substantial upheaval (bouleversement) of the economic equilibrium between the two sides. ${ }^{41}$ Similar principles may be found in narrow usages within a specific industry, or broader trade custom incorporated into principles promulgated by the Rome-based International Institute for the Unification of Private Law. ${ }^{42}$ These 'UNIDROIT Principles' attempt to suggest how commercial parties should react to dramatic and unforeseen circumstances that interfere with the performance of contract duties, either through excuse of performance, adaptation of the contract obligation, or a duty to re-negotiate, failing which the contract terminates. ${ }^{43}$

34 See Bristol Groundschool Limited et al. v Alexander John Whittingham [2014] EWHC 2145 (Chancery), 2014 WL 2957875 (2 July 2014), discussing Yam Seng Pte Ltd v International Trade Corp [2013] EWHC 111. See generally Chitty on Contracts (31st Ed. 2012), Chapter 23 (Discharge by Frustration).

35 See generally E. Allan Farnsworth, Contracts (2d ed. 1990), $\S \S 9.5$ - 9.7 at 5700-727. See e.g., Northern Ind. Public Service Co. v. Carbon County Coal Co. 799 F2d 265, at 278 (7th Cir. 1986), suggesting that a fixed price contract constitutes an explicit assignment of risk of market price increase to the seller and market price decreases to the buyer.

36 That being said, the synthesis of common law attempted by Uniform Commercial Code Section 2-615, designed for sale of goods, says that delay or non-delivery will not be deemed a breach of seller's duty if performance has been made "impracticable by the occurrence of a contingency the non-occurrence of which was a basic assumption on which the contract was made..."

37 See e.g., Missouri Pub. Serv. Co. v. Peabody Coal Co., 583 S.W.2d 721 (Mo. Ct. App. 1979), involving a price escalation clause which failed to track inflation properly. The court rejected arguments that the counterparty owed a good faith duty to renegotiate. See also USX Corp. v. Int'l Minerals \& Chemicals Corp., 1987 WL 20427, (N.D. Ill. 1987) on reconsideration in part, 1988 WL 119094 (1988) and 1989 WL 10851 (1989). See generally, John P Bermingham, Extending good faith: does the UCC impose a duty of good faith negotiation under changed circumstances?, 61 St John's Law Review 223 (1987); Carla Spivack, Of Shrinking Sweatsuits and Poison Vine Wax: A Comparison of Basis for Excuse Under U.C.C. § 2-615 and CISG Article 79, U. Pa J. Int'l Econ. L. 27 (2006) 774.

38 See e.g., French Code civil Article 1148 (force majeure as a defense to performance) and Article 1134(3), discussed supra, concerning the duty to execute contracts in good faith.

39 Italian Codice Civile, Articles 1467-68.

40 See German Bürgerliches Gesetzbuch Article 275 precluding claims for performance of an act which is impossible (unmöglich).

${ }^{41}$ These principles may be invoked on the basis of industry custom and commercial usage. See for example French Code civil art 1135 (consideration not only of expressed terms, but also of 'l'usage') and art 1511 of the French Code de procédure civile which for international arbitration directs application of 'des usages $d u$ commerce'. cf arts 1135 and 1511 with art 21 of the International Chamber of Commerce Arbitration Rules (2012 Version), stipulating that the tribunal 'shall take account of ... any relevant trade usages'.

42 Principles of International Commercial Contracts, issued first in 1994, then re-issued with modifications in 2004 and 2010. See also Commission on European Contract Law ('Lando Principles') chaired by Danish law Professor Ole Lando, presented in full in 1998.

43 The UNIDROIT Principles contain a section on 'Hardship' defined to exist when events fundamentally alter the equilibrium of the contract because the cost of performance has increased or the value received has diminished. The concept of hardship includes (inter alia) events that could not reasonably have been taken into account at the time of conclusion of the contract and whose risk was not assumed by the party. In the event of hardship the party may request renegotiation. On failure to reach an agreement a court may either (i) 'terminate the contract at a date and on terms to be fixed' or (ii) 'adapt the contract with a view to restoring its equilibrium'. See UNIDROIT Principles, arts 6.2.2 and 6.2.3. 


\section{Gas price adjustment revisited}

The relationship of national law to price revision is not limited to general principles of good faith or abuse of rights. As discussed earlier in connection with the Atlantic LNG case, arbitrators often engage in price adjustment of energy contracts pursuant to explicit terms in the agreement, ${ }^{44}$ attempting to provide a mechanism to address substantially changed circumstances. The contract might allow arbitrators to create a new price formula in light of changes affecting the value of gas obtained by a 'prudent' gas company so as to let the buyer market the gas 'economically'. 45

The price adjustment clauses appear to echo principles borrowed from public international law as expressed in notions of pacta sunt servanda ('agreements are to be kept') ${ }^{46}$ interpreted in conjunction with the corollary principle clausula rebus sic stantibus, to the effect that the agreement is binding 'so long as things stand as they are'. ${ }^{47}$

On closer reflection, such clauses may prove more malleable than initially expected. ${ }^{48}$ Does marketing 'economically' mean to sell in a way that is 'stingy' and cheap? Or does it mean to market in a way that is economically sound? Either meaning might fit.

National law enters the picture through the side door of an overarching applicable law clause, providing for contract interpretation according to principles found in the legal system of some 'third country' not that of either side to the contract, perceived as neutral between the parties or perhaps especially developed in the substance of the contract, such as English law has been for maritime matters. That applicable law may have something to say about how the controverted words should be interpreted.

In this connection, one recollects the old Latin maxim noscitur a sociis: a word is known by the company it keeps. Context dictates meaning, with words taking a different

44 See generally, Mark Levy (ed), Gas Price Revision (2014), with essays by Mark Levy, Michael Young Marnix Leijten and Martje de Vries Lentsch, Philippe Pinsolle, Michael Polkinghorne, George von Mehren, Tristram Kennedy Harper, Colm Gibson, Boaz Mosell, David Mildon, Paul Griffin and Frances van Eupen. See also Ben Holland and Phillip Spencer Ashley, 'Natural Gas Price Reviews: Past, Present and Future' (2012) 30 JENREL.

45 The adjustment clause might contain a provision saying that arbitrators can review the Price Formula (usually a complex equation based on some index of energy values, already fixed in the agreement) to see whether that formula 'needs to be revised to reflect significant changes in the buyer's energy market which affect the value of gas in the buyer's end user market, as such value can be obtained by a prudent and efficient gas company'. If the formula does need to be revised, its modification might be mandated so as to 'allow the Buyer to market the gas economically' (or 'commercially' in some instances) under the assumption of 'sound marketing practices by prudent and efficient operations on the part of Buyer'.

46 The essence of the concept appears in Justinian's Code II.3.29 (chapter De Pactis): sancimus nemini licere adversus pacta sua venire et contrahentem decipere ('we shall not allow anyone to contravene his agreements and thereby disappoint (deceive) his contractor').

47 See e.g. Ian Brownlie, Principles of Public International Law (6th edn, 2003) 591-92. The corollary, of course, is that treaties are binding 'so long as things stand as they are' (the so-called clausula rebus sic stantibus). See generally, JL Brierly, The Law of Nations (1963), 317-45; FA Mann, Studies in International Law (1973) 327-59. Analogously, Article 79 of the Convention on International Sales of Goods dispenses with liability when failure of performance was due to "an impediment beyond [the non-performing party's] control" which could not reasonably be expected to have taken into account at the time of contract conclusion. See Article 62, Vienna Convention on Law of Treaties, which addresses "Fundamental Change of Circumstances" and makes provision for a change whose effect is to "radically transform the extent of the obligations still to be performed under the treaty." See generally, Detlev Vagts, Rebus Revisited: Changed Circumstances in Treaty Law, Columbia Journal of Transnational Law, 43, 2005, page 459.

48 Thus some observers challenge the utility of the notions 'pact sunt servanda' (contracts to be performed) and its corollary ' rebus sic stantibus' (assuming things remain the same), suggesting that they are too broad and general to be helpful in practice. 
sense from divergent sentences. Our feet run. Our noses run. One might see a run on the bank. $^{49}$

Of course, use of national law as an interpretative tool carries its own problems. Principles developed in a domestic context might be pressed into service to construe a controverted term used in different international circumstances. ${ }^{50}$ What is a 'prudent' gas company? The 'prudent' standard in national law might derive from cases regarding utility rates, ${ }^{51}$ fiduciary obligations for trustees or a duty to mitigate damages, rather than marketing gas purchased from overseas. ${ }^{52}$

\section{Reliability and arbitration}

Much of the impulse to arbitrate international disputes might be explained as a response to specters of uncertainty, whether lying in the 'hometown justice' of another country's judicial system, or the perceived volatility of a civil jury in a far-away land. In the face of such hesitations, arbitration has been pressed into service to create more level litigation playing fields and to reduce the risk of random results. ${ }^{53}$ In a sense, arbitration serves the risk averse (or just plain prudent) who can accept with relative equanimity the likelihood of being up only one dollar (rather than two or three) as the cost of reducing prospects of ending with nothing at all. ${ }^{54}$

The inclination towards certainty and reliability might also explain differences in how arbitrators and judges approach application of national law. Although perceptions exist in some quarters that arbitrators may be less reliable than judges in applying the law, the opposite is often true, particularly in international cases.

This gap between reality and perception arises in part because of oft-repeated contentions that arbitrators 'split the baby' through awards not justified in law. ${ }^{55}$ Certain strains

49 Linguists sometimes describe phenomenon by word 'polysemy'. If someone says 'I get it' this might mean 'I understand' or 'I receive it' or 'I buy it' or 'I catch a disease'.

50 The opposite might also happen. An offshore contract might have been originally negotiated by domestic parties, but become international when one side assigned its rights to a foreign party.

51 Texas Public Utility Commission, Application of El Paso Electric Company for Authority to Change Rates, 10 Tex PUC Bull 1071, 1984 WL 274081 (Tex PUC) (7 December 1984)

52 For example, New York courts have said that an injured party who makes an effort to avoid or reduce damages may be allowed to recover related expenses if the effort was made, inter alia, prudently and efficiently. Den Norske Ameriekalinje Actiesselskabet $v$ Sun Printing \& Publishing Ass'n, 122 NE 463 (NY 1919). Even in oil and gas leases, the word 'prudent' might change from one context to another, whether relating to the operator's drilling decisions, production operations or marketing. See eg Gary B Conine, 'The Prudent Operator Standard: Applications beyond the Oil and Gas Lease' (2001) 41 Nat Res J, 23.

53 Those engaged in international transactions tend to think in relative terms, with a rule deemed reliable if it reduces the likelihood of alternate outcomes, not because it operates with perfect foreseeability. Any legal system may, on some issues, work to one side's disadvantage in a particular case. However, an agreement to 'play by the rules' of a relatively evolved system of law in a neutral forum will normally maximize both parties' ex ante expectation of fair treatment.

54 To illustrate the point, a group of students might signify an interest to work as research assistant for a professor in exchange for $\$ 1000$. A quite different response would obtain to a proposal that payment be deferred to the end of the academic year when a coin toss would determine whether the students receive, in the alternative, either double compensation or no payment at all.

55 The imagery of baby splitting seems to originate in the Biblical child custody dispute decided in ancient Jerusalem by King Solomon. When one woman accused another of stealing her baby, the King called for a sword so the child might be divided in two, with one half for each woman. Of course, the metaphor hides the character of Solomon's decision, which was not a final award. Rather, custody was ultimately granted to the real mother whose compassion led to abandonment of claims in hopes of saving the child. 1 Kings 3:23-28. 
of literature assert, without any real substantiation, that arbitrators render unprincipled decisions to attract business through re-appointment. ${ }^{56}$

In fact, no empirical data permits a conclusion on the matter, at least not from variations in records of 'win rates' in comparable cases, to the extent they can be determined, or the size of damages in arbitration as opposed to court litigation. ${ }^{57}$ Indeed, some studies of debt collection show that debtors may actually fare better in arbitration than in court. ${ }^{58}$

The greater reliability often found in arbitral awards, as contrasted with court judgments, often derives from a calculus of duty which differs between judge and arbitrator. Bearing obligations to the citizenry as a whole, judges may seek to implement societal values that sometimes trump private agreements. Although responsible judges will master existing authority before taking the law in new directions, many traditions allow appellate judges to overrule precedent. In some legal systems, judicial policy pre-dispositions have led political scientists to engage in intricate charting of ideology in court judgments. ${ }^{59}$

No similar social engineering will normally fall to arbitrators. As creatures of the parties' consent, arbitrators must show special fidelity to shared expectations expressed in contract or treaty, fixing their eyes on existing norms rather than proposals for the law as it should be. ${ }^{60}$

Sometimes, relatively clear and specific contract language competes with more general provisions of national law. In such instances, arbitrators in international cases may show a heightened sensitivity towards the predictability of contract terms. Although sensitive to public values, rejecting complicity with illicit schemes and abusive procedures, arbitrators fix their eyes more on existing legal norms, asking what the parties had a right to expect. When interpreting the law, arbitrators may be more inclined to take statutes and cases as

56 Richard A Posner, How Judges Think (2008) 127-28, stating that courts and juries are 'more likely to adhere to the law and less likely than arbitrators to "split the difference" between the two sides thereby lowering damages'. As authority, the book cites a California case, Armendariz v Foundation Health Psychcare Services, 6 P 3d 669, 693 (Cal 2000), which states, 'The perceived advantages of the judicial forum for plaintiffs include the availability of discovery and the fact that courts and juries are viewed as more likely to adhere to the law and less likely than arbitrators to "split the difference" between the two sides, thereby lowering damages awards for plaintiffs.' That case in turn quotes a law review article which says that corporate defendants like arbitration because it is purportedly pro-business. See David S Schwartz, 'Enforcing Small Print to Protect Big Business: Employee and Consumer Rights Claims in an Age of Compelled Arbitration' (1997) 33 Wis L Rev 60-61, citing the 1968 Second Circuit decision in American Safety Equipment Corp. $v$ J.P. Maguire \& Co., 391 F 2d 821 (2d Cir 1968) later discredited by the US Supreme Court in Mitsubishi Motors $v$ Soler Chrysler-Plymouth, 473 US 614 (1985).

57 See eg Daphna Kapeliuk, 'The Repeat Appointment Factor' (2010) 96 Cornell L Rev 47, analyzing 131 ICSID cases implicating almost 200 arbitrators, refuting the oft-bandied suggestion that arbitrators either act in a biased way (to please appointers) or render decisions giving each party a partial victory to increase user satisfaction. The author suggests that an arbitrator's incentive to maintain a reputation for independence and credibility trumps any temptation to act in an inappropriate way. See also Theodore Eisenberg and Elizabeth Hill, 'Arbitration \& Litigation of Employment Claims: An Empirical Comparison' (ABA, Nov 2003-Jan 2004) 58 Disp Res J 44, looking at state and federal court trials as compared with AAA arbitrations.

58 Christopher R Drahozal and Samantha Zyontz, 'Creditor Claims in Arbitration and in Court' (2011) 7 Hastings Bus L J 77; Christopher R Drahozal, 'Arbitration Innumeracy' (2012) 4 Ybk Arb Med 89. Any evaluation of the argument that arbitrators are biased in consumer cases must look at comparable cases decided in the same way by arbitrators and in court. Professor Drahozal contrasts creditor win rates of $85.2 \%$ and $97.1 \%$ in arbitration with creditor win rates of $98.4 \%$ and $100 \%$ for debt collection cases in court. ibid 93-94.

59 See eg Jeffrey A Segal and Harold J Spaeth, The Supreme Court and the Attitudinal Model Revisited (CUP, 2002). The so-called 'Martin-Quinn Scores' use a scale with negative numbers translating to liberalism and positive numbers translating to conservatism. Thus Justice Douglas, considered a liberal judge, received an average ideological score of minus 4 , while a score of positive 4.30 was accorded the conservative Justice Rehnquist.

60 On whether Continental arbitrators must follow domestic case law, see Klaus Peter Berger, 'To What Extent Should Arbitrators Respect Domestic Case Law? The German Experience Regarding the Law on Standard Terms' (2015) 31 Arb Int'l (forthcoming). 
they are, rather than considering public policies that justify shape or stretch norms to meet new social or economic challenges.

On occasion, the nature of the judicial office may include a perceived institutional duty to embrace public interests of the forum, or a political inclination to develop the law in light of evolving national concerns of a social or economic nature. In a dispute over the price of oil, a judge in a fuel-importing jurisdiction like Massachusetts could be expected to consider payments by local residents during the bitter cold New England winters. ${ }^{61}$ By contrast, arguments for lower fuel costs might be received with greater scepticism by judges from oil producing countries like Venezuela.

Of course, personal sympathies can play a role for both arbitrators and judges. ${ }^{62}$ For the disciplined arbitrator, however, whether from Boston or from Caracas, the duty towards the contracting parties and the correct interpretation of their agreement will tend to manifest itself in a heightened fidelity to the parties' shared ex ante expectations, and thus predictable vindication of contract rights. ${ }^{63}$

Such variations in the approaches of arbitrator and judge tend to be linked to their respective sources of authority. The genesis of judicial power normally lies in the political collectivity that appoints the judge and pays his or her salary. By contrast, the arbitrator's legitimacy starts with an agreement to waive recourse to otherwise competent national courts. ${ }^{64}$ The arbitrator may look to enhance shared ex ante expectations of the parties themselves, applying the law on an 'as is' basis. By contrast, the appellate judge might explore principles that push law into new directions, so as to promote certainty from the perspective of emerging policy.

In an international context, bias and fairness often appear as opposite sides of the same coin. The party for which a rule creates commercial disadvantage will welcome a softening of that rule's rigour by a judge in its home forum. By contrast, the foreign side might perceive failure to enforce the bargain as simply xenophobic prejudice. ${ }^{65}$

61 On occasion, it has been argued that public interests come into play more for investor-state arbitration than for commercial disputes. On reflection, however, contract disputes will be seen to affect the world's aggregate social and economic welfare no less than investment treaty controversies. If the financial crisis of 2008 demonstrates anything, it teaches that private choices have public consequences. To some extent, the debate may be about terminology. See eg, 'Theory and Reality of the Arbitrator' (2013) 7 World Arb Med Rev 629-49, including proceedings of the 25th Annual Workshop of the Institute for Transnational Arbitration in Dallas in June 2013.

62 See eg Edna Sussman, 'Arbitrator Decision Making: Unconscious Psychological Influences and What You Can Do about Them' (2013) 24 Am Rev Int'l Arb 487.

63 For a broader treatment of what has been called arbitration's 'ambivalence toward law' see Jan Paulsson, The Idea of Arbitration (2013) 13-18.

64 As suggested by Professor Pierre Mayer, constraints on the international arbitrator derive from 'the will of the parties, the jurisdictional nature of the arbitral function, and in modern legal systems only minimally from mandates at the arbitral seat'. Pierre Mayer, 'La liberté de l'arbitre' (2013) 2 Revue de l'arbitrage 340. In the original, '[Les contraintes sur l'arbitre] tiennent à la volonté des parties, à la nature juridictionnelle de sa fonction et, dans les législations modernes, seulement dans une faible mesure à certains impératifs émanant de l'Etat du siège.'

65 Imagine, for example, that a gas supply agreement between an Algerian state agency and a Boston importer operates to the disadvantage of the American buyer. A court judgment refusing to enforce certain aspects of the contractual arrangements might appear as promoting community interests in Massachusetts. From the perspective of the Algerian seller, however, the judicial decision would likely seem simply as a way to ignore the parties' freely accepted agreement to enhance post-dispute local interests. See eg, Sonatrach v Distrigas Corp., 80 Bankr 606 (D Mass 1987). In reversing a lower court decision which, at the request of the Massachusetts importer, had denied enforcement of an arbitration agreement invoked by the Algerian seller, the Federal District Court for Massachusetts opinioned, 'It is important and necessary for the United States to hold its domiciliaries to their bargains and not allow them to escape their commercial obligations by ducking into statutory safe harbors.' ibid 614. 
The observation that arbitrators may be more inclined to apply the law than judges does not mean, of course, that arbitrators cannot on occasion reach for notions of commercial justice contrary to legal norms of the day. Such may happen particularly when a contract makes explicit reference to notions of justice and equity. In some instances, the arbitral award may even announce a trend in legal thought later incorporated into positive law. ${ }^{66}$

Finally, the way arbitrators apply law on the merits of the dispute interacts with what evidence they can consider, a matter that sometimes lies on the border between procedure and substance. ${ }^{67}$ Under the law of certain jurisdictions, but not others, arbitrators and judges may look at post-contract comportment to interpret contract terms. Determining when a contract term might be 'ambiguous' often complicates matters further. ${ }^{68}$

\section{Conclusion}

In energy contracts, the role of gap filling and the effect of changed circumstance will resist facile analysis, given the wide variety of national standards and distinction in contract language that interact with the myriad factual matrixes in which disputes arise. Notwithstanding the challenges, arbitrators cannot just give up and say, "This is too hard for me!"

Even if a single "right" solution proves elusive, wrong paths will often be identifiable. A delicate equilibrium exists between legitimate respect for the parties' bargain and an equally legitimate recognition of the parties' expectation that genuine gaps be filled and dramatically changed circumstances receive consideration. In achieving such counterpoise, common sense normally pays greater dividends than ideology.

66 See Panhandle Grain \& Elevator Co. v Dorsey, 242 SW 255 (Tex Civ App, San Antonio 1922). The seller was to deliver 10,000 pounds of cane seed in 'sound, strong bags'. The buyer initially rejected the shipment on the ground that it had not been properly sacked. The buyer then rejected the seller's offer to re-sack the seed and protect the buyer against any loss. An arbitration panel of the Grain Dealers' Association gave an award in favour of the seller. The award was enforced notwithstanding the state of the law at the time, which apparently gave the buyer a right to rescind. The court noted a stipulation that the arbitral decision should be according to 'justice and equity'. Later, the law of sales (Uniform Commercial Code and Convention on International Sale of Goods) evolved along the lines favoured in arbitration, with a seller's right to 'cure' defects in tendered goods.

67 See Uniform Commercial Code s 2-208. When a sales contract involves repeated occasions for performance, with knowledge of the nature of the performance and the opportunity for objections, such course of performance 'accepted or acquiesced in without objection shall be relevant to determine the meaning of the agreement'. Compare English law as set forth in Schuler \& Wickham, 1974 AC 235 (HL 1974) and Whitworth Estates v James Miller [1970] AC 572. Of course, post-contract behaviour might be relevant for claims based on estoppel rather than contract terms. English law is equally restrictive on recourse to statements made during negotiation. See Charterbrook Ltd v Persimmon Homes Ltd [2009] 1 AC 1101, paras 41-42, excluding evidence of 'what was said or done during the course of negotiating the agreement'. Such rules are usually put forward as parts of English substantive law, rather than procedure. The matter is of importance, given that s 34 of the 1996 English Arbitration Act grants the arbitral tribunal significant discretion to 'decide all procedural and evidential matters' absent the parties' agreement otherwise. Evidential and procedural matters are defined to include rules on 'relevance or weight of any material (oral, written, or other) sought to be tendered on any matters of fact or opinion'.

68 Complexity, of course, does not mean ambiguity. See Re Lehman Brothers, 478 BR 570 (SDNY 2012) (Barclays Capital Inc. et al. $v$ James W. Giddens, as Trustee for SIPA Liquidation of Lehman Brothers), addressing inter alia when New York law permits examination of material outside the four corners of the agreement. 